\title{
2'-5'-Oligoadenylates as a «tool» of innate immunity
}

\author{
Z. Yu. Tkachuk \\ Institute of Molecular Biology and Genetics, NAS of Ukraine \\ 150, Akademika Zabolotnogo Str., Kyiv, Ukraine, 03680 \\ ztkachuk@bigmir.net
}

\begin{abstract}
It is a matter of common knowledge, that «core» 2'-5'-oligoadenylates and their analogues posses broader biological activity than it can be predicted within the traditional «interferon» hypothesis. They exhibit immunomodulatory effects and are effective immunosuppressive agents upon organ and tissue transplantation. Oligoadenylates render antiviral activity against a wide range of viruses both DNA and RNA origin. These drugs regulate apoptosis, cell proliferation and possess antitumor activity. Such polyvalent activity is based on their ability to bind signaling proteins, slightly altering their conformation and modulating their activity. They can also change the secondary structure of both viral DNA and RNA, making them accessible for enzymatic cleavage. The hypothesis forwarded within this review is aimed at making an attempt to explain the mechanism of 2'-5'-oligoadenylates antiviral action. Our recent papers, containing experimental data to support this hypothesis, are discussed in this review.
\end{abstract}

Keywords: 2'-5'-oligoadenylate, 2'-5'-oligoadenylatsyntase, interferon a, protein kinases, $\mathrm{Ca}^{2+}$-binding proteins, RNA-, DNA- containing viruses.

At the end of the seventies Ian Kerr initiated the study on the 2'-5'-adenylate system (2'-5'-A) of the general formula $\operatorname{pppA}(2 \mathrm{pA}) \mathrm{A}_{n}(n=1-3)$ and drew attention to its role in initiation of a metabolic pathway inhibiting intracellular viral replication [1]. The 2'-5'-A system plays an important role in the cascade of interferon (IFN)-induced biochemical reactions [2]. It was at that time that the action of 2'-5'-oligoadenylates on regulation of cell growth, oncogene expression, cellular differentiation, and their role in cellular response to changes in hormonal milieu was established. 2'-5'-oligoadenylates inhibit DNA synthesis in different cell cultures [3], exhibit anti-mutagenic properties [4] and influence the natural killer cell activity [5]. 2'-5'- $\mathrm{A}_{3}$ core analogs also exert a wide range of biological actions [6]. Summarizing the advances in the study of 2'-5'-oligoadenylates in the mid-eighties, the leading American newspaper, The Wall Street Journal, reported that the one who would unravel the mechanism of antiviral action of 2'5 -oligoadenylates, would be capable of synthesizing a

(C) Institute of Molecular Biology and Genetics, NAS of Ukraine, 2013 broad spectrum antiviral agent comparable to «antiviral penicillin».

IFN is capable to induce 2'-5'-oligoadenylate synthetase (2'-5'-OAS) activity, that in the presence of double-stranded (ds) RNA converts ATP into 2'-5'-linked oligomers of adenosine with the general formula pppA $\left(2^{\prime} \mathrm{p}-5^{\prime} \mathrm{A}\right)_{n}$. Experimental findings demonstrate that this biochemical reaction cascade is the key mechanism of antiviral IFN properties: $p p p\left(2^{\prime}-5^{\prime}\right) \mathrm{A}_{n}$ can bind to and activate the latent RNase $\mathrm{L}$ which degrades viral and cellular RNA. The 2'-5'-OAS/RNase L pathway plays a pivotal role in the innate antiviral immunity. This is the pathway by which RNase L destroys viral RNA and cellular mRNAs regardless of their origin. Its function is maintained by IFNs, cytokines, a number of signalling proteins, including protein kinases and $\mathrm{Ca}^{2+}$-binding proteins. As it will be further discussed, oligoadenylates are not only involved in antiviral immunity, but also may effectively suppress allograft rejection and mediate antitumour immunity. Phosphorylated oligoadenylate $\operatorname{ppp}\left(2^{\prime}-5^{\prime}-\right) \mathrm{A}_{n}$ is actively metabolized in cells and is cleaved by 2 '-phosphodiestherase or 5'-phosphatase. In the 
latter case, it is converted to a 5 '-diphosphorylated core $\left(2^{\prime}-5^{\prime}-\mathrm{A}_{n}\right)$.

Oligoadenylates have been found in almost all eukaryotic cells. The range of their intracellular concentration is wide, depending on the functional specificity of a cell, the phase of the cell cycle. Intracellular concentration of oligoadenylates also changes in case of viral infection. The normal 2'-5'-A intracellular concentration is below $1 \mathrm{nM}$. It can increase dozens of times and reach $10 \mathrm{nM}$ in case of 2'-5'-OAS induction by IFN or a virus [7].

Analogs of 2'-5'- $\mathrm{A}_{n}(n=3)$ also possess a number of biological properties, and, therefore, are of considerable interest as well [8]. Based on the example of 2'-5'$\mathrm{A}_{3}$ analogs including well-known antimetabolites 9-(beta-D-xylofuranosyl) adenine 2'-5'-A 1 -epoxy and 3'-deoxyadenosine $2^{\prime}-5^{\prime}-\mathrm{A}_{3}$ cord in their structure, it has been shown that they exhibit activity against the type 1 and type 2 herpes virus. Under the influence of cellular phosphodiesterase, the core trimmers are hydrolyzed to the respective nucleoside-5'monophosphates and nucleosides with their characteristic activity [9].

On the other hand, it has been shown quite convincingly that $2^{\prime}-5^{\prime}-\mathrm{A}_{3}$ and their analogs exhibit their own characteristic activity as trimmeric compounds [10]. It should be emphasized that these core trimmers mimic many of the IFN effects in the cells $[8,9]$.

The advantage of the use of 2 '-5'- $\mathrm{A}_{3}$ oligoadenylate analogs is related to their biological activity. They break down slowly under the influence of phosphodiestherase and maintain a long-lasting activity as compared with T-lymphocytes (about 2 weeks). They are easily synthesized in large quantities with the help of the readily available chemical synthetic techniques [11].

Since they are the analogs of the natural products, when used in effective dosages they show little or no toxic activity and exhibit no adverse effects on other important functions of the organism. Normally, three component analogs of 2'-5'- $\mathrm{A}_{3}$ oligoadenylates, used singly or in a combination, are used with modifications in ribose positions $2^{\prime}$ and $3^{\prime}$ of the third terminal adenosine moiety.

The identified biological properties of «core» 2'-5'$\mathrm{A}_{3}$ and their analogues allowed us to make assumption about their ability to affect the structure and function of a wide range of antiviral immunity proteins. Accoding to this hypothesis we performed our studies.
Immunomodulating properties. As in vivo phosphodiesterases hydrolyze 2'-5'- $\mathrm{A}_{3}$ to simple compounds (adenosine and adenosine-5'-monophosphate), we proposed a new method, and synthesized 2'-5'- $\mathrm{A}_{3}$ analogs which were found to be more resistant to the action of phosphodiesterases (Figure). Subsequently, we selected the most active analogs. The most promising analogs appeared to be 9-(2,3-anhydro-beta-D-ribofuranosyl) adenine (2'-5'- $\mathrm{A}_{3}$ epoxy) and 9-(2,3-anhydro-betaD-lyxofuranosyl) adenine (2'-5'-A 1 -epoxy) [12]. Both analogues were found to be resistant to the action of snake venom phosphodiesterase. For example, 2'-5'- $\mathrm{A}_{3}$ epoxy appeared to be 35-fold more resistant as compared with its prototype 2 '-5'- $\mathrm{A}_{3}$ [13].

Immunomodulating properties of core $2^{\prime}-5^{\prime}-\mathrm{A}_{3}$ and their analogs were studied on a model of a delayed-type hypersensitivity reaction (DTHR). 2'-5'-A $\mathrm{A}_{3}$ was found to exhibit the most potent immunostimulating effect, while its analog 2'-5'-A $\mathrm{A}_{3}$ epoxy, on the contrary, inhibited DTHR. The effect was dependent on the concentration of a cytostatic agent, thiophosphamide. Other analogs, such as 2'-5'- $\mathrm{A}_{3}$ epoxy, 2'-5'- $\mathrm{A}_{3}$ (xylose and arabinose derivatives) were not found to possess any immunosuppressive action. 2'-5'- $\mathrm{A}_{3}$ epoxy, in contrast to the natural 2'-5'- $\mathrm{A}_{3}$, exhibited a much more marked action upon blast-transformation reaction of lymphocytes both in vitro and in vivo. Therefore, 2'-5'- $\mathrm{A}_{3}$ was concluded to possess immunostimulating properties, while its analog 2'-5'- $\mathrm{A}_{3}$ epoxy was found to have immunosuppressive properties [14].

Further studies of 2'-5'-A analogs have shown that 2'-5'-A $\mathrm{A}_{3}$ epoxy and 2'-2'-5'-A 1 -epoxy exhibit a potent immunosupressive action specifically aimed against $\mathrm{T}$ killer and T-helper cells. A single injection of 2'-5'$\mathrm{A}_{3}$ epoxy suppresses in vivo the number of T-killers and T-helpers by $50 \%$ within $48 \mathrm{~h}$. Comparative analysis of the activity of different analogs showed that 2'-5'-A epoxy was more resistant to the action of phosphodiesterase than 2'-5'-A $\mathrm{A}_{3}$-epoxy and suppressed more actively the number of T-killer and T-helper cells [15]. Therefore, in further experiments 2'-5'- $\mathrm{A}_{3}$ epoxy was used as an immunosuppressor in animal models of renal transplantation. In rabbits, injections of 2 '-5'-A epoxy provided normal functioning of the kidney transplant for a period of 3 months. T-lymphocyte blast-transformation in post-transplanted rabbits stimulated with 

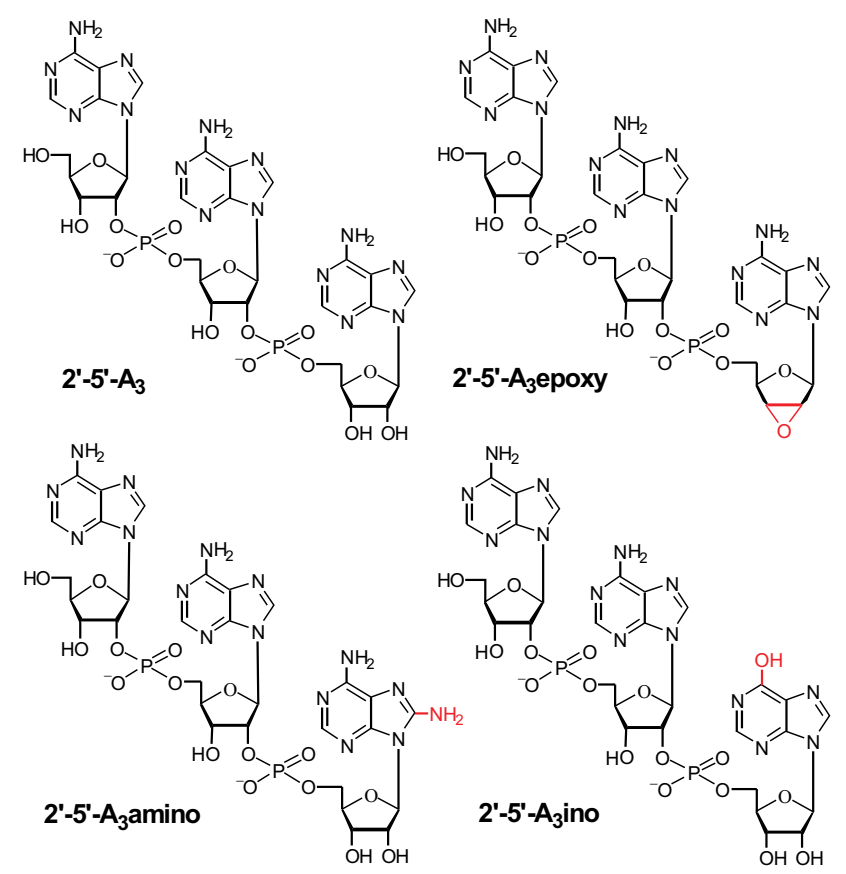

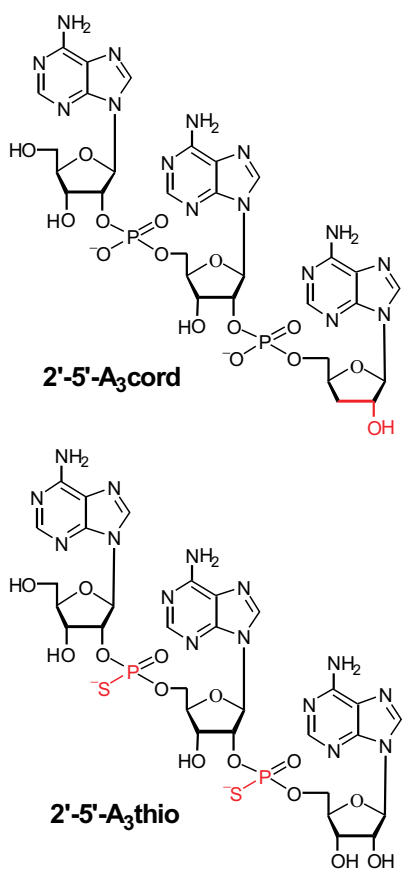

Structures of $2^{\prime}-5^{\prime}-\mathrm{A}_{3}$ and its analogues
Concavalin A was suppressed by almost 10-fold [12]. In monkeys, intravenous administration of 2'- 5'-A $\mathrm{A}_{3}$ epoxy protected the transplant against rejection, and promoted the recovery of function of the transplanted kidney. A dose-dependent response was found to the action of 2'-5'-A $\mathrm{A}_{3}$ epoxy upon the number of T- killer and T-helper cells in the blood of transplanted animals and elevated levels of $\alpha$ - and $\beta$-interferons, which are markers of antiviral and antibacterial protection [12-15].

Therefore, 2'-5'- $\mathrm{A}_{3}$ epoxy may be used as an immunosuppressive agent in transplantation of kidneys, heart, lungs, bone marrow and other organs. It can be also used in the treatment of T-cell-mediated immune disorders, in autoimmune diseases, and in lymphocytic tumors.

Antiviral action. Biological activity of $2^{\prime}-5^{\prime}-\mathrm{A}_{3}$ and their analogs was studied on different groups of viruses. 2'-5'- $\mathrm{A}_{3} \mathrm{xylo}$ has been shown to possess a potential antiviral activity against Herpes simplex type 1 and type 2 virus [9], and 2'-5'- $A_{3}$ has inhibited viral mRNA synthesis, without action upon the growth of non-infected by Herpes simplex virus cells [16]. 2'-5'- $\mathrm{A}_{3}$ inhibited replication of the virus Sindbis and vesicular stomatitis virus in a human angioma cell culture [17]. 2'$5 '-\mathrm{A}_{3}$ analogs proved to be effective as inhibitors of reproduction of retroviruses. A $2^{\prime}-5^{\prime}-\mathrm{A}_{3}$ analog, containing 3'-cordycepin instead of 2'-5'-A3cord was found to inhibit HIV-1 reverse transcriptase [18].
We studied the antiviral activity of 2'-5'- $\mathrm{A}_{3}$ and their analogs on a phage $\lambda$ model. These agents were shown to induce self-destruction of the phage $\lambda$ DNA, thus eliminating its infectivity [19]. The effect of core 2'-5'-A upon the enzymes of nucleic acids metabolism was also studied. EcoRI, BamHI and HindIII restrictases in the presence of some 2'-5'-A $\mathrm{A}_{3}$ were shown to be inhibited, as well as to cause the loss of site specificity of the phage $\lambda$ DNA and to alter the restrictase functional activity. In the latter case they act as non-specific DNAses. This effect depends on the structure of 2'-5'-A, its concentration and restrictase type. Cordycepin analog of 2'-5'-A was ten times more effective as compared with the natural core [20].

Subsequently, we studied the characteristics of the $\lambda$ phage native DNA hydrolysis by $\mathrm{S} 1$ nuclease in the presence of 2'-5'-A and their analogs. Incubation of 2'-5'-A with the native $\left[{ }^{3} \mathrm{H}\right]$-thymidine-labled DNA of phage $\lambda$ results in formation of a large number of portions of singlestranded DNA $\lambda$ available for hydrolysis. The degree of hydrolysis depended on $2^{\prime}-5^{\prime}-\mathrm{A}_{3}$ concentration and its structure. Nucleotides and nucleosides did not exhibit that type of activity. Two- and four-member «cores» 2'5'-A and their analogs had a weaker effect upon the secondary DNA structure. These data permit to assume that 2 '-5'-A influences the secondary DNA $\lambda$ structure, promoting thus the formation of single-stranded portions 
which can be cleaved by S1 nuclease. This phenomenon can not be explained by activation of nuclease $\mathrm{S} 1$ by $2^{\prime}-5^{\prime}-\mathrm{A}_{3}$, as inhibition of hydrolysis was demonstrated when melted DNA was used in the same conditions [21].

Stacking effect has been observed with 2'-5'-oligoadenylates, especially with 2 '-5'- $\mathrm{A}_{3}$. Stacking characteristics of 2'-5'-A $\mathrm{A}_{3}$ presumably provide the action upon the DNA structure in a way resulting in formation of single-stranded portions. The influence of 2'-5'- $\mathrm{A}_{3}$ and their two- and four-member analogs upon the secondary structure of polynucleotides was studied with the help of a micro calorimetric method. The obtained results on a model of RNA- and DNA-like polynucleotides confirm our suggestion that the action of 2'-5'-A cores is aimed at alteration of the secondary structure of nucleic acids. Moreover, the study of synthetic polynucleotides confirms the possibility of immediate interaction of $2^{\prime}-5^{\prime}-A_{3}$ with nucleic acids. It is important that only three-member 2 '-5'- $\mathrm{A}_{3}$ are capable to alter the polynucleotide structure [22].

The capacity of 2'-5'- $\mathrm{A}_{3}$ to get delivered inside the cell and to influence the secondary DNA structure was studied on a model of a fibroblast cell culture. The labeled core ${ }^{3} \mathrm{H}-2^{\prime}-5^{\prime}-\mathrm{A}_{3}$ was shown to bind to fibroblast cells in low concentrations, and this process appeared to depend on the incubation time. Analysis of unbound ${ }^{3} \mathrm{H}-2^{\prime}-5^{\prime}-\mathrm{A}_{3}$ in a suprasediment fluid showed that only 2 to 4 per cent of $2^{\prime}-5^{\prime}-\mathrm{A}_{3}$ gets delivered to cells.

The possible influence of exogenous 2 '-5'- $\mathrm{A}_{3}$ on intracellular DNA was studied by assessment of the change of DNA structure, using fluorescent propidium iodide. Incubation of 2'-5'-A $A_{3}$ with fibroblast cells yielded a general increase of fluorescence intensity up to $20 \%$. Hence $2 '-5 '-\mathrm{A}_{3}$, when delivered inside the cell, may increase the number of propidium iodide binding sites.

To study the possible damage of intracellular fibroblast DNA by $2^{\prime}-5^{\prime}-\mathrm{A}_{3}$, fibroblasts were treated with nuclease $\mathrm{S} 1$. As nuclease $\mathrm{S} 1$ is active against singlestranded DNA, it was hypothesized that interaction of $2^{\prime}-5$ '- $\mathrm{A}_{3}$ with cellular DNA results in formation of single-stranded DNA portions, subject to hydrolysis by the enzyme. Incubation of fibroblast cells with 2'-5'- $\mathrm{A}_{3}$ and nuclease $\mathrm{S} 1$ resulted in a significant decrease of fluorescence intensity. Therefore we suggested that doublestranded nucleic acids may be one of the intracellular targets of 2'-5'- $\mathrm{A}_{3}[23]$.
In summary, experiments with $\mathrm{S} 1$ nuclease and phage $\lambda$ DNA as well as with fibroblast cell culture demonstrated that 2'-5'-A may influence the structure of a double-stranded DNA. These effects are observed even if delivery of 2'-5'- $\mathrm{A}_{3}$ inside the cells is relatively low. It can be suggested that antimitogenic and antiviral properties (including those against DNA viruses) may be associated with immediate action upon a double-stranded structure of nucleic acids, beyond the action of RNase L. Thus, the action of 2'-5'- $\mathrm{A}_{3}$ cores (the synthesis of which is induced by IFN system) is possibly aimed at alteration of the secondary structure of the viral nucleic acids, causing their rapid destruction by cellular nucleases regardless of the virus origin.

It is noteworthy, however, that the antiviral effect of IFN is associated with the antiviral action of IFNinduced ppp2'-5'- $\mathrm{A}_{n}$, although not in all cases. This permits to suggest that there may be other yet undiscovered mechanisms of antiviral action of 2'-5'-oligoadenylates. We studied the antiviral action of 2'-5'- $\mathrm{A}_{3}$ epo$\mathrm{xy}$, in particular its action upon HIV-1 reproduction, interferonogenic activity, and action upon reverse transcriptase activity of both exogenous and endogenous retroviruses. Pretreatment with 2'-5'- $\mathrm{A}_{3}$ and 2'-5'- $\mathrm{A}_{3}$ epoxy was shown to be associated with a decrease of HIV infectivity due to an increase of IFN concentration, as well as with suppression of reverse trancriptase activity of HIV and Moloney murine leukemia virus. The study of kinetics of reverse transcriptase inhibition by 2'-5'- $\mathrm{A}_{3}$ and its epoxy analog proved them to be non-competitive reverse transcriptase inhibitors of both retroviruses [24].

We further studied the antiviral action of 2'-5'- $\mathrm{A}_{3}$ and its analogs on RNA-containing swine transmissible gastroenteritits virus and Aujeszky disease virus. 2'$5^{\prime}-\mathrm{A}_{3}$ and $2^{\prime}-5^{\prime}-\mathrm{A}_{3}$ epoxy were shown to lower the titer of varicella vaccine virus by more than $2,5 \mathrm{lg}$ TCD (tissue cytopathic doses). The study of action of 2'-5'- $\mathrm{A}_{3}$, 2'-5'- $\mathrm{A}_{3}$ epoxy, and 2'-5'- $\mathrm{A}_{3}$ xylo on reproduction of swine transmissible gastroenteritits virus and Aujeszky disease virus showed that they have different modes of action. In particular, in case of Aujeszky disease virus which belongs to a herpesviridae family, 2'-5'- $\mathrm{A}_{3}$ is of potential interest as it appeared to lower the virus titer by $1,77 \mathrm{lg} \mathrm{TCD}$. In case of swine transmissible gastroenteritits virus, 2'-5'- $\mathrm{A}_{3}$ epoxy was found to be the most ac- 
tive. This finding indicates the potential advantages its use against corona viruses. 2'-5'- $\mathrm{A}_{3}$ epoxy exhibited the antiviral effect regardless of the mode of its delivery into the cell, while 2'-5'- $\mathrm{A}_{3} \mathrm{xylo}$ did not exhibit any antiviral effect on the above-mentioned viruses. The obtained results, therefore, permit to suggest that the studied olygoadenylates realize their antiviral properties on different groups of viruses [25].

Antitumor action. 2'-5'-A are intracellular mediators of not only IFN, but also of a number of different cytokines. In particular, 2'-5'-A-synthetase stimulation is observed under the action of epidermal growth factor, tumor necrosis factor [26] interleukins 1 and 6 [27, 28 ], and transforming growth factor $\alpha$ [29] upon the cells. Induction of 2'-5'-A system activity is seen not only in viral infections, but also in other pathological states of the organism: type 1 diabetes mellitus [27], chronic fatigue syndrome [30], and in heat shock [31]. In the recent years significant progress has been achieved in the study of action of these substances upon normal and transformed nervous cells. In particular, 2'-5'$\mathrm{A}_{3}$ has been shown to be able to induce the differentiation of neuroblastoma cells [32] and myoblasts [33]. Another analog, 2'-5'- $\mathrm{A}_{3}$ ether, inhibited the proliferation of transformed breast cells [34] .

It is evident that 2-5A and their analogs have a high biological activity; therefore, we studied their antiproliferative action. The influence of 2'-5'- $\mathrm{A}_{3}$ epoxy in vitro on cultivated cells of human neuroblastoma was studied. $2 '-5 '-\mathrm{A}_{3}$ epoxy was shown to decrease the number of cultivated cells and to increase the protein content as compared with control. $\mathrm{Na}, \mathrm{K}^{+}$- and $\mathrm{Ca}^{2+}, \mathrm{Mg}^{2+}$-ATP-ase activity in a microsomal fraction obtained from cells cultivated in presence of 2'-5'- $\mathrm{A}_{3}$ epoxy, was shown to be twofold lower than in the control cells. The obtained results confirm that 2'-5'- $\mathrm{A}_{3}$ epoxy possesses antiproliferative activity and modulates significantly the activity of $\mathrm{Na}^{+}, \mathrm{K}^{+}$- and $\mathrm{Ca}^{2+}, \mathrm{Mg}^{2+}$-ATP-ases. The processes of normal cellular growth and division are known to depend on the concentration gradients of $\mathrm{Na}^{+}, \mathrm{K}^{+}, \mathrm{Mg}^{2+}$ and $\mathrm{Ca}^{2+}$ ions. This permits to suggest that significant decrease in $\mathrm{Na}^{+}, \mathrm{K}^{+}$- and $\mathrm{Ca}^{2+}, \mathrm{Mg}^{2+}$-ATP-ase activity observed in our experiments is one of the major factors contributing to antiproliferative effect of 2'-5'- $\mathrm{A}_{3}$ epoxy. 2'-5'-A $A_{3}$ epoxy may be regarded as substances with a significant potential for their use in pharmacological therapy of neurogenic tumors [35]. 2'-5'- $\mathrm{A}_{3}$ was demonstrated to be able to modulate significantly the ion transport mechanisms in human neuroblastoma cells [36].

Further studies of the action of $\alpha 2 b$-IFN and of 2'5 '-oligoadenylates upon the cultivated in vitro human neuroblastoma cells confirmed the one-way action of IFN, 2'-5'- $\mathrm{A}_{3}$ and 2'-5'- $\mathrm{A}_{3}$ epoxy within the cell. Both $\alpha 2 b-I F N$ and 2'-5'-oligoadenylates inhibit cellular proliferation, increase the intracellular protein content, modulate the sodium and calcium transport mechanisms [37]. The one-way action of IFN and of oligoadenylates was confirmed by the other investigators who studied the antiproliferative effect of these agents in concanavalin A-stimulated murine lymphocytes [38]. Two hypotheses were proposed to explain this phenomenon. According to the first hypothesis 2'-5'- $\mathrm{A}_{3}$ when delivered inside the cell, gets phosphorylated by the kinases present inside, and acts as ppp2'-5'- $\mathrm{A}_{3}$ [39]. According to the second hypothesis, $2^{\prime}-5^{\prime}-\mathrm{A}_{3}$ competitively inhibits ppp2'-5'-A hydrolysis [40]. According to both hypotheses the intracellular content of ppp2'-5'- $\mathrm{A}_{3}$ increases. However, these both hypotheses do not take into consideration the fact that IFN, in contrast to ppp2'-5'- $\mathrm{A}_{3}$, activates the Jak/STAT signaling pathway through binding with specific superficial receptors, resulting in the signal transduction from the cell receptor to nucleus and activation of the early response genes, including the gene of 2'-5'-oligoadenylate synthetase. Transfection of ppp2'-5'- $\mathrm{A}_{3}$ in physiological concentrations into a cell was shown to cause induction of certain genes, including IFN-stimulated genes [41]. Probably, this discovery explains the mechanism of the one-way action of IFN and $2^{\prime}-5^{\prime}-\mathrm{A}_{3}$. Most likely, they can influence the gene expression of the innate immunity by mimicking the effects of one another.

Proliferation, apoptosis and migration of bone marrow cells. After the discovery of the role of stem cells in homeostasis of the organism, an intensive study of agents capable of stimulating bone marrow stem cell proliferation (BMC) in sub endosteal area was initiated. We investigated the influence of $2^{\prime}-5^{\prime}-\mathrm{A}_{3}$ agents and their analogs on stem cells content of blood. The natural 2'-5'- $\mathrm{A}_{3}$ core and its analog 2'-5'-A $\mathrm{A}_{3}$ epoxy were shown to inhibit apoptotic processes in the studied cells and stimulate BMC proliferation by approximately 2fold as compared with control. However, 2'-5'- $\mathrm{A}_{3}$ epoxy 
differs from the natural core by exhibiting a somewhat higher activity with regard to apoptotic and proliferative processes of BMC. The influence of $2^{\prime}-5^{\prime}-\mathrm{A}_{3}$ and $2^{\prime}-5^{\prime}-\mathrm{A}_{3}$ epoxy on migration of stem BMC in mice after syngenic transplantation was also investigated. 2 '-5'- $\mathrm{A}_{3}$ and $2^{\prime}-5^{\prime}-\mathrm{A}_{3}$ epoxy were found to stimulate the migration of stem BMC almost 2-fold as compared with control. The 10-fold decrease of concentration of these agents did not affect significantly the migration of stem $\mathrm{BMC}$, and, respectively, the number of spleen colonies in the recipient mice [42].

The influence of $2^{\prime}-5$ '-A on cellular regulatory systems. The proliferative action of 2'-5'-A cores and their analogs is supposedly associated with activation of the cAMP system, manifesting as the change of intercellular cAMP level [43]. Considering the strong interrelationship and interdependence between 2'-5'-A and cAMP systems, we evaluated the association between the action of 2'-5'-A analogs upon cell cultures and animal organs, on one side, and concentrations of cAMP and cGMP in these cells and tissues, on the other side. Incubation of T-lymphocytes with 2'-5'- $\mathrm{A}_{3}$ epoxy was shown to be associated with an increase of cAMP levels, while $2^{\prime}-5$ '- $\mathrm{A}_{3}$ decreased cAMP levels by approximately 2 -fold [44].

In experiments in vivo after administration of 2'-5'- $\mathrm{A}_{3}$ epoxy after 1 hour the plasma level of cAMP was observed increased 2-fold, as compared with the control. As for natural 2'-5'- $\mathrm{A}_{3}$, it failed to change the levels of cAMP and cGMP in blood plasma samples. Administration of 2'-5'- $\mathrm{A}_{3}$ epoxy resulted in almost 2-fold increase of cAMP levels in the mouse liver. Similar experiments with evaluation of spleen showed other results. 2'-5'- $\mathrm{A}_{3}$ epoxy and 2'-5'-A $\mathrm{A}_{3}$ caused 2-2.5-fold lowering of cAMP, while cGMP level remained the same as it was in the liver. Therefore, 2'-5'- $\mathrm{A}_{3}$ analogs, in contrast to natural 2'-5'- $\mathrm{A}_{3}$, when introduced into animal organs and tissues, influence the cAMP levels in a concentration-dependent manner, and do not affect the cGMP levels [44].

The action of inductors of proliferation and of cyclic nucleotides is known to depend on the concentration of the $\mathrm{Ca}^{2+}$ ions [45]. As the 2'-5'-A system is related to cAMP, it can be hypothesized that a stimulating action of 2-5A and their analogs depends on the intracellular calcium metabolism. Similar mechanisms are involved in the function of arterial smooth muscle cells. Thus, the aim of our study was to investigate a possible role of core 2'-5'- $\mathrm{A}_{3}$ and 2'-5'- $\mathrm{A}_{3}$ epoxy in the mechanism of regulation of smooth muscle cells of the aorta and of the femoral artery. We demonstrated the inhibiting effect of these agents upon smooth muscle cells through the activation of $\mathrm{Ca}^{2+}$-dependent potassium conductance. The action of 2'-5'- $\mathrm{A}_{3}$ may be eliminated by the use of high-conductance calcium-activated potassium channel blockers $\left(\mathrm{BK}_{\mathrm{Ca}}\right)$ or by a protein kinase $\mathrm{A}$ inhibitor. The inhibition of vasodilating action of 2'-5'-triadenylate by cAMP-dependent protein kinase may imply that 2 '-5'-A can inhibit vasoconstriction through activation of cAMPdependent protein kinase by 2 '-5'- triadenylate. In addition, cAMP-dependent protein kinase can phosphorylate $\mathrm{BK}_{\mathrm{Ca}}$ channels, thus, activating them. It can also act upon other proteins involved in the contraction-relaxation of smooth muscle cells [46].

Subsequently, we investigated the action of 2'-5'- $\mathrm{A}_{3}$ on intracellular $\mathrm{Ca}^{2+}$ metabolism on a model of pituitary tumor cells (GH3). The membrane of GH3 cells is known to contain two types of channels which are activated by low (LVA) and high voltage (HVA). The activity of these voltage-gated channels depends on phosphorylation of membrane proteins involved in ion transportation, including transportation of the calcium ions. Phosphorylation is catalyzed by protein kinases; therefore, the changes of current flux through voltage-gated calcium channels may be used as a marker of degree of phosphorylation of membrane-binded proteins and a marker of the overall intracellular function.

We studied the action of core 2'-5'- $\mathrm{A}_{3}, 2^{\prime}-5^{\prime}-\mathrm{A}_{3}$ epoxy and $3^{\prime}-5$ '- $\mathrm{A}_{3}$ upon phosphorylation-dependent $\mathrm{Ca}^{2+}$ channels in GH3 cells. Experiments on these cells revealed an increase in the amplitude of phosphorylationdependent $\mathrm{Ca}^{2+} \mathrm{L}$-currents and prolongation of progressive decline of the amplitude of these currents. Core 2'$5^{\prime}-\mathrm{A}_{3}$ and their analogs exhibit similar action upon increase and decrease of $\mathrm{Ca}^{2+}$ currents of HVA, and thus, possibly, on the increase of the intercellular phosphorylation level [47].

L-carrents flowing through the $\mathrm{Ca}^{2+}$ channels are known to be interrelated with the activation of protein kinases $\mathrm{A}$ and $\mathrm{C}$. We performed a molecular modeling of interaction between $2^{\prime}-5^{\prime}-\mathrm{A}_{3}$ (and their modified ana$\operatorname{logs}$ ) and protein kinase C. $2^{\prime}-5^{\prime}-\mathrm{A}_{3}$ and their analogs were shown to get binded with protein kinase $\mathrm{C}$ within 
a katalytic center on the enzyme. 2'-5'- $\mathrm{A}_{3}$ epoxy was characterized by the most effective binding and by the most compact location within the active protein kinase center. Binding depends on the number of adenosine chains, the trimmers being the most favorable for binding. 2'-5'- $\mathrm{A}_{3}$ and protein kinase $\mathrm{C}$ interaction is supposed to cause stimulation of protein kinase $\mathrm{C}$ interaction with $\mathrm{IP}_{3}$-receptors and further release of $\mathrm{Ca}^{2+}$ ions [48].

Action upon the function of signal proteins. The obtained results permitted us to suggest the possible mechanism of action of core 2'-5'- $\mathrm{A}_{3}$, involving their binding with cellular signal proteins which, in its turn, results in significant alteration of conformation of these proteins and may significantly modulate their activity, either increasing or decreasing it. First and foremost, this is pertinent to protein kinases and $\mathrm{Ca}^{2+}$-binding proteins.

We found direct evidence that core 2'-5'- $\mathrm{A}_{3}$ and their analogs modulate the activity of eight different protein kinases either stimulating or inhibiting proteinase activity. The most prominent inhibitory activity is exhibited by $2^{\prime}-5^{\prime}-\mathrm{A}_{3}$-amino analog, containing the 8 -aminoadenosine compound. The titrimetric curves of titration of protein kinase Aurora with 2'-5'- $\mathrm{A}_{3}$ and 2'-5'- $\mathrm{A}_{3}$ epoxy were not linear having $\mathrm{V}$ - or $\mathrm{W}$-shaped [49]. We suggest that interactions with $2^{\prime}-5^{\prime}-\mathrm{A}_{3}$ and their analogs may occur beyond the fuctionally active sites of protein kinases, leading to the changes of protein conformation and thus, to the changes of enzyme activity. The findings demonstrating the capacity of 2'-5'- $\mathrm{A}_{3}$ to not only inhibit, but also to stimulate protein kinase activity, favour this suggestion. That is why it is possible that 2'$5^{\prime}-\mathrm{A}_{3}$ and its analogs modulate the activity of protein kinases by causing their conformational changes.

Various extracellular and intracellular signals cause the increase of cytoplasmatic ionized $\mathrm{Ca}^{2+}$ levels. Calcium, in its turn, actively interacts with calcium-binding proteins, in particular with calmodulin. Calmodulin is a small protein with a molecular weight of $18.000 \mathrm{Da}$. Considering the results discussed above, we suggested that 2'-5'-A $\mathrm{A}_{3}$ get binded with calmodulin thus influencing its conformation and functional activity. The use of pure calmodulin demonstrated that 2'-5'- $\mathrm{A}_{3}$ and $2^{\prime}-5^{\prime}-\mathrm{A}_{3}$ epoxy significantly increase the degree of binding of labeled ${ }^{45} \mathrm{Ca}^{2+}$ with this protein. 2'-5'- $\mathrm{A}_{3}, 2^{\prime}-5^{\prime}-\mathrm{A}_{3}$ epoxy and $2^{\prime}-5^{\prime}-\mathrm{A}_{3}$ cord increase three-fold the affinity of calmodulin to calcium ions. 2 '-5'- $\mathrm{A}_{3}$ cord significantly in- creased the maximal binding capacity of $\mathrm{Ca}^{2+}$ with calmodulin. Therefore, calmodulin represents a molecular target for 2'-5'- $\mathrm{A}_{3}$ and its analogs, which by increasing the affinity of this protein to $\mathrm{Ca}^{2+}$ ions, activate the process of this cation binding [50].

We assume that other target proteins of core 2'-5'$\mathrm{A}_{3}$ are present in cells. The search for these proteins and the study of their interactions with 2'-5'-oligoadenylates would permit to establish some fundamental mechanisms of regulation of cellular processes as well as to develop new therapeutic agents. 2'-5'- $\mathrm{A}_{3}$ agents were shown to decrease effectively the fluorescence of albumin, and to a lesser extent that of IFN. This is a proof of interaction and binding of oligoadenylates with these proteins. Their interaction in most cases occurs in the presence of tyrosine compounds, while the role of tryptophan is usually less significant. These agents practically did not affect the emission of immunoglobulin G. The 2-5- $\mathrm{A}_{3}$-amino analog appeared to be the most effective ligand of INFs, with tryptophan playing a key role in this interaction $[51,52]$.

We applied the method of low temperature autoluminescence for spectral testing of albumin binding with oligonucleotides. Due to structured spectra of autophosphorescence at low temperatures, the binding of human albumin with 2'-5'-A $\mathrm{A}_{3}$ molecules was confirmed $[53,54]$.

Many works dedicated to the study of biological activity of 2'-5'-A demonstrated that the mechanism of their antiviral action is related to their capacity to act upon the proteins of 2'-5'-oligoadenylatsynthetase/endoribonuclease L (2'-5'-OAS/RNase L) system, which, in its turn, leads to the destruction of viral RNA. However, the main role in the antiviral defence belongs to IFNs which not only induce the expression of genes involved in the antiviral cellular mechanisms, but also, according to the recent studies of Silverman, can get selfactivated by oligonucleotide products of viral RNA cleavage produced by RNase L [55].

From here a question is arises regarding the capacity of core 2'-5'- $\mathrm{A}_{3}$ and 3'-5' $\mathrm{A}_{3}$ to bind directly with IFN, and thus to influence its functions. The study of protein-oligonucleotide interactions was performed with the use of mass-spectrometry (MALDI-TOF). 3'-5'-A, $2^{\prime}-5^{\prime}-\mathrm{A}_{3}$ and its epoxy analog were demonstrated to be capable of binding with $\alpha$-IFN. Core 2'-5'- $\mathrm{A}_{3}$ and 3'-5'$\mathrm{A}_{3}$ have multiple interactions with $\alpha$-IFN resulting in 
formation of stable complexes. They do not bind with insulin which is not a component of a 2'-5'-OAS/RNase system $[56,57]$.

The conformational changes in IFN, calmodulin and S100A1 were studied with the use of Fourier transform infrared spectroscopy (FTIR). Changes of absorption spectrum were found in all complexes of the studied proteins and 2'-5'- $\mathrm{A}_{3}$, corresponding to the amide I and amide II regions which are known as indicators of the state of the secondary structure of a protein globule. Moreover, the changes were revealed in the 1200-1100 $\mathrm{cm}^{-1}$ region, indicating the contribution of $2^{\prime}-5^{\prime}-\mathrm{A}_{3}$ carbohydrate component to the interaction with target proteins. The above data serve as a direct proof of binding of the studied proteins with $2^{\prime}-5^{\prime}-\mathrm{A}_{3}$ and their influence on their conformation [58].

With the use of a circular dichroism spectroscopy (CD-spectroscopy) the changes of secondary structures of the protein S100A1 were studied. The protein apo (without $\mathrm{Ca}^{2+}$ ions) and holo (with $\mathrm{Ca}^{2+}$ ions) forms were investigated. $\mathrm{S}_{100 \mathrm{~A}_{1}}$ exists as a homodyne which is expressed in the heart tissue where it plays an important regulatory role in the $\mathrm{Ca}^{2+}$ homeostasis. In our study, with the use of $\mathrm{CD}$ and fluorescent spectroscopy we have established that 2 '-5'- $\mathrm{A}_{3}$ influences the structure and function of $\mathrm{S}_{100 \mathrm{~A}_{1}}$. The $\mathrm{CD}$ spectra have demonstrated that 2 ' -5 '- $\mathrm{A}_{3}$ causes small conformational changes in apo-S100A $\mathrm{A}_{1}$ structures. The structural changes are predominantly localized in the linker region and/or in the $\mathrm{C}$-terminal region of the spiral IV. The analysis of the binding constant shows that 2'-5'- $\mathrm{A}_{3}$, probably binds

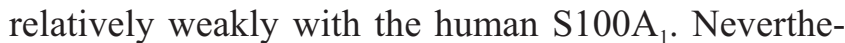

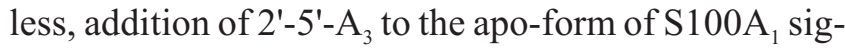
nificantly increases the $\mathrm{Ca}^{2+}$-binding constants. Interestingly, this effect is more noticeable in the presence of epoxy 2'-5'-A derivative. Therefore, our studies show that binding of 2'-5'- $\mathrm{A}_{3}$ causes small structural changes in $\mathrm{S}_{100 \mathrm{~A}_{1}}$ leading to the increase of affinity of $\mathrm{Ca}^{2+}$ to the protein. They may be considered as a proof of «soft influence» during 2'-5'- $\mathrm{A}_{3}$ and $\mathrm{S}_{100 \mathrm{~A}_{1}}$ interaction.

Summarizing the data from literature and the results of our studies, we can state that the cores of 2'-5'-oligoadenylates and their analogs possess a significantly wider spectrum of biological activity than predicted within the limits of the traditional «interferon» hypothesis. They exhibit immunomodulating action as well as they act as very effective immunosupressants, thus being able to regulate reactions of transplanted organ or tissue rejection. Oligoadenylates possess a wide spectrum of activity against both DNA- and RNA-containing viruses. These agents regulate apoptosis and proliferation of cells, possess an antitumor activity and influence the contraction of smooth muscle cells. It is clear that such multidirectional activity should be based on characteristic molecular mechanisms allowing them to participate in such a wide spectrum of biological effects. All the above-named biological effects of these substances seem to fit into the system of innate defense, including cAMP, $\mathrm{Ca}^{2+}$-binding proteins, protein kinases, interferons and cytokines, 2'-5'-oligoadenylate synthetase and RNase $\mathrm{L}$, restrictases, nucleases, and other proteins.

We attempted to study these proteins, in part, and to find the common characteristics permitting these substances to perform their regulatory functions. With the use of various techniques we have established that oligoadenylates can bind with signal proteins with a association constant of about $10^{-5}-10^{-6} \mathrm{M}$. This leads to conformational changes of the signal proteins and hence to the changes of their affinity and modulation of the activity. These are the principal properties of oligoadenylates with regard to signal proteins.

Considering the established properties of oligoadenylates, we proposed a hypothesis explaining the mechanism of their antiviral action. According to this hypothesis, the cores of 2'-5'-oligoadenylates, formed as a result of ppp2'-5'-A and RNase L interaction, change the structure of viral DNAs and RNAs in a way that they become exposed to cleavage by cellular nucleases, phosphodiesterases, and phosphatases. They can also cause conformational changes of viral and cellular receptors, inhibiting virus entry and exit from cells. Simultaneously, oligoadenylates by changing the conformation of the signaling molecules, may influence proliferation of the immune cells as well as migration of bone marrow stem cells. Acting upon the expression of genes of cellular defense, and, first of all, those of cytokines, they may regulate the balance between inflammatory and antiinflammatory processes.

The commercialization of synthetic $2^{\prime}-5^{\prime}-\mathrm{A}_{3}$ analogs in pharmaceutical industry was weighed down by extremely high cost of their production. Therefore, based on the hypothesis suggested in 2000 , we separated from 
yeasts a relatively cheap substance consisting of natural oligonucleotides. This substance was the basis for development and introduction into medical practice of a medication Nucleinat, possessing immunomodulating and antiinflammatory properties $[59,60]$. This medication appears to be especially effective in the chronic inflammatory processes accompanied by immunodeficiency. In 2010, industrial processing of this substance resulted in development of Nuclex, a broadspectrum antiviral agent possessing the antiviral properties of 2'-5'- $\mathrm{A}_{3}$ analogs, and active against various RNA- and DNA-containing viruses [61]. Further studies of the role of oligoadenylates in the regulation of signaling pathways and gene expression of the innate immunity will permit to precise the spectrum of natural therapeutic oligonucleotides and their potential for regulation of the innate antitumor defense. This appoach gives hope for developing effective antitumor agents the action of which would be aimed at the regulation of the host antitumor defense system.

\section{3. Ю. Ткачук}

2'-5'-олігоаденілати як «інструмент» уродженого імунітету

\section{Резюме}

Відомо, щ⿻о «кори» 2'-5'-олігоаденілатів та їхніх аналоги володіють значно ширшою біологічною активністю, ніж ие можна передбачити в рамках традичійної «інтерферонової» гіпотези. Вони проявляють імуномодулюючу дію і є ефективними імуносупресорами при трансплантації органів і тканин. Олігоаденілатам притаманна противірусна активністю стосовно широкого спектра як ДНК-, так і РНК-вмісних вірусів. Ці препарати регулюють апоптоз і проліферацію клітин та володіють протипухлинною активністю. Така полівалентна активність олігоаденілатів базується на можливості зв'язуватися з сигнальними білками, щзо призводить до зміни їхньої конформації та модуляції активності. Вони також можутьпорушувати вторинну структуру вірусних ДНК і РНК і роблять їх доступними для розщеплення клітинними ферментами. Запропоновано гіпотезу, яка пояснюе механізм противірусної дї 2'-5'-олігоаденілатів, а також наведено експериментальні дані на їі користь.

Ключові слова: 2'-5'-олігоаденілати, 2'-5'-олігоаденілатсинтетаза, $\alpha$-інтерферон, протеїнкінази, $\mathrm{Ca}^{2+}-$ зв 'язувальні білки, РНК-, ДНК-віруси.

\section{3. Ю. Ткачук}

2',5'-олигоаденилаты как «инструмент» врожденного иммунитета

Резюме

Известно, что «коры» 2'-5'-олигоаденилатов и их аналоги обладают более широкой биологической активностью, чем это можно предположить в рамках традиционной «интерфероновой» ги потезы. Они проявляют иммуномодулирующее действие и явля- ются эффективными иммуносупрессорами при трансплантации органов и тканей. Олигоаденилатам присуща антивирусная активность относительно широкого спектра как ДНК-, так и РНКсодержаших вирусов. Эти препараты регулируют апоптоз и пролиферацию клеток и обладают противоопухолевой активностью. Такая поливалентная активность олигоаденилатов базируется на возможности связываться с сигнальными белками, что приводит к изменению их конформации и модуляции активности. Они также могут нарушать вторичную структуру вирусных ДНК и РНК и делать их доступными для расщепления клеточными ферментами. Предложена гипотеза, объясняюшая механизм противовирусного действия 2'-5'-олигоаденилатов, и приведены экспериментальные данные в ее пользу.

Ключевые слова: 2'-5'-олигоаденилаты, 2'-5'-олигоаденилатсинтетаза, а-интерферон, протеинкиназы, $\mathrm{Ca}^{+2}$-связываюшче белки, РНК-, ДНК-содержашие вирусы.

\section{REFERENCES}

1. Kerr I. M., Brown R. E. ppp A2'poA2'p5'A: an inhibitor of protein synthesis synthesized with an enzvme fraction from interferon-treated cells // Proc. Natl Acad. Sci. USA.-1978.-75, N 1.P. 256-260.

2. Johnston M. I., Torrence P. F. The role of interferon-induced proteins, double-stranded RNA and 2', 5'-oligoadenylate in the interferon-mediated inhibition of viral translation // Interferon: mechanisms of production and action / Ed. R. M. Friedman.Amsterdam: Elsevier, 1984.-Vol. 3.-P. 189-298.

3. Williams B. R. G., Silverman R. H. Preface // The 2-5A system: molecular and clinical aspects of the interferon-regulated pathway / Eds B. R. G. Williams, R H. Silverman.-New York: A. R. Liss, 1985.-P. 21-22.

4. Eppstein D. A., Schryver B. B., March Y. V. et al. Dephosphorylated core of 2'-5'-oligoadenylate exerts its antimitogenic effect through mechanisms different from the 2'-5'A-dependent endonuclease // J. Interferon Res.-1983.-3, N 3.-P. 305-311.

5. Black P. L., Henderson E. E., Pfleiderer W. et al. 2',5'-Oligoadenylate trimer core and the cordycepin analog augment the tumoricidal activity of human natural killer cells // J. Immunol.-1984.135, N 5.-P. 2773-2777.

6. Torrence P. F., Imai J., Lesiak K. et al. Strategies agents in the design of oligonucleotides as potential antiviral // Targets for the design of antiviral agents / Eds E. DeClercq, R. T. Walker.-New York: Plenum Press, 1984.-P. 259-285.

7. Sawai H., Ishibashi K., Itoh M., Watanabe S. Radioimmunoassay for 2-5A using a novel labeled 2-5A analog, and analysis of 2-5A and 2-5A synthetase activity in human plasma // The 2-5A system: molecular and clinical aspects of the interferon-regulated pathway Eds B. R. G. Williams, R. H. Silverman.-New York: A. R. Liss, 1985.-P. 97-104.

8. Suhadolnik R. J., Doetsch P. W., Devash Y. et al. (2'-5')-Adenylate cordecypin trimer cores: metabolic stability and evidence for antimitogenesis without 5'-rephosphorylation // Nucleosides Nucleotides.-1983.-2, N 4.-P. 351-366.

9. Eppstein D. A., Marsh Y. V., Schryver B. B. Mechanism of antiviral activity of (XyloA2'p) $)_{2}$ XyloA // Virology.-1983.-131, N 2.P. 341-354.

10. Johnston M. I., Torrence P. F. The role of interferon-induced proteins, double-stranded RNA and (2'-5'-)oligoadenylate in the interferon-mediated inhibition of viral translation // Interferon: mechanisms of production and action / Ed. R. M. Friedman.Amsterdam: Elsevier, 1984.-Vol. 3.-P. 189-298. 
11. Kvasyuk E. I., Kulak T. I., Khripach N. B. et al. Nucleotides XXIV. Preparative synthesis of trimeric (2'-5') oligoadenylic acid // Synthesis.-1987.-1987, N 6.-P. 535-541.

12. United States Patent 5, 571, 799. (2'-5')oligoadenylate analogues useful as inhibitors of host-v-graft response / Tkachuk Z., Kvasyuk E., Matsuka G., Mikhailopulo I.; November 5, 1996.

13. Kozlov A. V., Tkachuk Z. Yu. Study of 2', 5'-oligoadenylate analogs stability to the action of phosphodiesterases // Biopolym. Cell.-1994.-10, N 1.-P. 47-52.

14. Kozlov A. V., Tkachuk Z. Yu., Slukvin I. I. et al. 2'-5'- oligoadenylates effect on certain indexes of immune response // Biopolym. Cell.-1994.-10, N 3-4.-P. 52-57.

15. Mikhailopulo I. A., Baran E. A., Koslov A. V. et al. Synthesis and use of 2'-5'-oligoadenylate trimers modified at the 2'-terminus in kidney transplantation in rabbits and monkeys // Nucleosides Nucleotides.-1995.-14, N 3-5.-P. 1105-1108.

16. Fujihara M., Milligan J. R., Kaji A. Effect of 2',5'-oligoadenylate on herpes simplex virus-infected cells and preventive action of 2',5'-oligoadenylate on the lethal effect of HSV-2 // J. Interferon Res.-1989.-9, N 6.-P. 691-707.

17. Tominaga A., Saito S., Kohno S. et al. Antiviral effects of 2',5'oligoadenylates (2-5As), and related compounds // Microbiol. Immunol.-1990.-34, N 9.-P. 737-747.

18. Montefiori D. C., Sobol R. W. Jr., Li S. W. et al. Phosphorothioate and cordycepin analogues of 2',5'-oligoadenylate: inhibition of human immunodeficiency virus type 1 reverse transcriptase and infection in vitro // Proc. Natl Acad. Sci. USA.-1989.-86, N 18.-P. 7191-7194.

19. Tkachuk Z. Yu., Tkachuk V.V., Tkachuk L.V., Matsuka G. Kh. Isolation and study (2'-5'-)oligoadenylate dependent deoxyribonucleas activity of the salmon milk DNA // Reports of the Academy of Sciences of Ukraine.-1991.-N 8.-P. 164-167.

20. Tkachuk Z. Yu., Tkachuk L. V., Kvasyuk E. L. et al. Changes in functional properties of restriction enzymes under the influence of (2'-5'-) oligoadenylates in vitro // Biopolym. Cell.-1989.-5, N 2.-P. 69-73.

21. Tkachuk Z. Yu., Tkachuk L. V., Kozlov A. V. et al. Influence (2'5'-)oligoadenylate for hydrolysis complex Nuclease S1 and DNA $\lambda$ in vitro // Reports of the Academy of Sciences of Ukraine.1988.-N 12.-P. 62-66.

22. Tkachuk Z. Yu., Kozlov A. V., Hasan A. I., Mikhailopulo I. A., Maleev V. Ya., Matsuka. G. Kh. Influens (2-5) oligoadenylate on the structure of polynucleotides // Reports of the Academy of Sciences of Ukraine.-1988.-N 12.-P. 81-84.

23. Tkachuk Z. Yu., Kozlov A. V., Tkachuk L. V., Phylozop T. L., Mlkhailopulo I. A. Detection of structural changes of nucleic acids under the action of 2'-5'-oligoadenylates // Biopolym. Cell.-1995.-11, N 2.-P. 82-87.

24. Tkachuk Z. Yu., Rybalko S. L., Semernikova L. I. et al. The effect of trimeric 2'-5'-oligo adenilic acid and its epoxy-derivative on human immunodeficiency virus (HIV-1) reproduction and retroviruses reverse transcriptase activity // New Microbiol.-1998.21, N 2.-P. 197-201

25. TkachukZ. Yu., Semernikova L. I., Tkachuk V. V. et al. Antiviral effect of trimeric 2', 5'-oligoadenylic acid and some of its analogues // New Microbiol.-1998.-21, N 2.-P. 141-146.

26. Wietzerbin J., Gaudelet C., Catinot L. et al. Synergistic effect of interferon-gamma and tumor necrosis factor-alpha on antiviral activity and (2'-5'-)oligo (A) synthetase induction in a myelomonocytic cell line // J. Leukoc. Biol.-1990.-48, N 2.-P. 149-155.

27. Petrovsky N., Kyvik K. O., Bonnevie-Nielson V. et al. Evidence from twins for acquired cellular immune hyperactivity in type 1 diabetes // Immunology.-2002.-106, N 4.-P. 584-589.
28. Cohen B., Gothelf Y., Vaiman D. et al. Interleukin-6 induces the (2'-5'-)oligoadenylate synthetase gene in M1 cells through an effect on the interferon-responsive enhancer // Cytokine.-1991.3, N 6.-P. 83-91.

29. Kumar R., Mendelsohn J. Growth regulation of A431 cells. Modulation of expression of transforming growth factor-alpha mRNA and 2'-5'-oligoadenylate synthetase activity // J. Biol. Chem.1990.-265, N 8.-P. 4578-4582.

30. Snell C. R., Vanness J. M., Strayer D. R., Stevens S. R. Physical performance and prediction of 2-5A synthetase/RNase L antiviral pathway activity in patients with chronic fatigue syndrome // In Vivo.-2002.-16, N 2.-P. 107-109.

31. Chousterman S., Chelbi-Alix M. K., Thang M. N. Heat-shock induced regulation of 2',5'oligoadenylate synthetase // The 2-5A System: Molecular aspects of the interferon-regulatad pathway / Eds B. R. G. Williams, R. H. Silverman.-New York; London: Alan R., Liss Inc., 1985.-P. 97-104.

32. Vyatchenko-Karpinski S. V., Pogorela N. X., Magura I. et al. Induction of morphological differentiation and modulation of ion channels caused by $\alpha 2$-interferon and oligoadenylate in neuroblastoma cells // Neurophysiology.-1995.-27, N 3.-P. 199-207.

33. Bisbal C., Silhol M., Laubenthal H. et al. The 2'-5' oligoadenylate/RNase L/RNase L inhibitor pathway regulates both MyoD mRNA stability and muscle cell differentiation // Mol. Cell. Biol.2000.-20, N 14.-P. 4959-4969.

34. Latham K. E., Cosenza S., Reichenbach N. L. et al. Inhibition of growth of estrogen receptor positive and estrogen receptor negative breast cancer cells in culture by AA-etherA, a stable 2-5A derivative // Oncogene.-1996.-12, N 4.-P. 827-837.

35. Rozhmayova O. M., Dolhaya E. V., Pohorelaya N. Ch. et al. Influence epoxy derivative 2'5-tryoligoadenilat on cell neuroblastom human cells // Neurophysiology.-2006.-38, N 2.-P. 97-102.

36. Rozhmayova O. M., Dolhaya E. V., Pohorelaya N. et al. Influence of dephosphorylated 2-5-tryoligoadenilat on entry sodium ions in the cells of human neuroblastoma // Neurophysiology.2008.-40, N 1.-P. 3-8.

37. Dolgaya E. V., Pogorelaya N. H., Rozhmanova O. M. et al. Modulation effect of derivative 2'5-tryoligoadenilat on cells human neuroblastoma // Imunologiya ta alergologiya.-2008.-N 4.P. 73-80.

38. Kimchi A., Shure H., Revel M. Regulation of lymphocyte mitogenesis by (2'-5')oligo-isoadenyiate // Nature.-1979.-282, N 5741.-P. 849-851.

39. Williams B. R., Kerr I. M. Inhibition of protein synthesis by 2'-5' linked adenine oligonucleotides in intact cells // Nature.-1978.276, N 5683.-P. 88-89.

40. Kimchi F., Shure H., Revel M. Anti-mitogenic function of interferon-induced ( $\left.2^{\prime}-5^{\prime}\right)$ oligo(adenylate) and growth-related variations in enzymes that synthesize and degrade this oligonucleotide // Eur. J. Biochem.-1981.-114, N 1.-P. 5-10.

41. Malathi K., Paranjape J. M., Bulanova E. et al. A transcriptional signaling pathway in the IFN system mediated by $2^{\prime}-5$ '-oligoadenylate activation of RNase L // Proc. Natl Acad. Sci. USA.2005.-102, N 41.-P. 14533-14538.

42. TkachukZ. Yu., Dubey I. Ya., Yakovenko T. G. et al. Synthesis of 2'-5'-oligoadenylates and study on their effect on proliferation and migration of bone marrow stem cells of mice in vitro and in vivo // Biopolym. Cell.-2007.-23, N 1.-P. 14-20.

43. Itkes $A$. $V$. Oligoadenylate and cyclic AMP: interrelation and mutual regulation // Progr. Mol. Subcell. Biol.-1994.-14.P. 209-221.

44. TkachukZ. Yu., TkachukV. V., TkachukL. V. et al. Influence of 2', 5' oligoadenilates and theirs analogues on the cyclic nucleo- 
tides level in vivo and in vitro // Biopolym. Cell.-2001.-17, N 5.P. 411-416.

45. Fedorov J. A. Cyclic nucleotides and leykogenez // Stem cells and tumor.-Kyiv: Nauk. dumka, 1985.-224 p.

46. Filippov I. B., Tkachuk Z. Yu., Dubey I. Ya. Mechanisms of vessel tone regulation by $2 /-5 /$-oligoadenylates // Reports of the National Academy of Sciences of Ukraine.-2010.-N 6.-P. 152-157.

47. Kostyuk P. G., Kozlov A. V., TkachukZ. Yu. et al. Effect of «core» 2 ',5-oligoadenylates on the phosphorylation-dependent calcium channels in GH3 cells // Ukr. Biokhim. Zh.-1995.-67, N 1.-P. 26-32.

48. Kozlov A. V., Kitam V. O., Tkachuk Z. Yu. Molecular model of the interaction of 2'-5 oligoadenylates with protein kinase C // Reports of the National Academy of Sciences of Ukraine.2009.-N 3.-P. 171-175.

49. Tkachuk Z. Yu., Kozlov A. V., Dubey I. Ya., Kukharenko A. P. 2'5'-Oligoadenylates and their analogs as modulators of activity of protein kinases $/ / 8^{\text {th }}$ Parnas Conf. (Warsaw, Poland, August 27 31,2011): Abstracts book.-Warsaw, 2011-P. 82.

50. Tkachuk Z. Yu., Dubey I. Ya., Tkachuk L. V., Dubey L. V., Shlykov S. G., Babich L. G. The effect of 2'-5'-Oligoadenylates on Calcium Binding to Calmodulin // The $17^{\text {th }}$ Int. Symp. on Calcium-Binding Proteins and Calcium Function in Health and Disease (July 16-21, 2011 Beijing, China 2011).-Beijing, 2011.P. 41

51. TkachukZ. Yu., Dubey L. V., Tkachuk V.V. et al. Study of the interaction of 2'-5'-oligoadenylates and their analogues with proteins by fluorescence spectroscopy // Ukr. Biokhim. Zh.-2011.83, N 1.-P. 45-53.

52. Tkachuk Z. Yu., Dubey L. V., Tkachuk V. V., Tkachuk L. V., Losytskyy M. Yu., Yashchuk V. M., Dubey I. Ya. The Interaction of 2'-5'-oligoadenylates with proteins // Late Abstract Book the $36^{\text {th }}$ FEBS Congr. Torino (Turin, 25-30 June, 2011).-Turin, 2011.-P. 8

53. Yaschuk V. M., Tkachuk Z. Yu., Levchenko S. M., Kudrya V. Yu., Mel'nik V. I., Vorob'ev V. P. Autophosphorescence proteins and polyribonucleotides and possibility of the spectral testing of their interaction // Biotechnology.-2012.-5, N 4.-P. 104-112.

54. Yashchuk V. M., Kudrya V.Yu., Levchenko S. M. et al. The Olygoadenilate nanosystems as the phosphorescence sensors for proteins transfer //E-MRS 2011 Spring Meeting (Nice, May, 9-13, 2011).-Nice, 2011.-P. 586.

55. Malathi K., Saito T., Crochet N. et al. RNase L releases a small RNA from HCV RNA that refolds into a potent PAMP // RNA.2010.-16, N 11.-P. 2108-2119.

56. Levchenko S. M., Rebriev A. V., Tkachuk V. V. et al. Studies on interaction of oligoadenylates with proteins in vitro by MALDITOF mass spectrometry // Biopolym. Cell.-2013.-29, N 1.P. 42-48.

57. Levchenko S. M., Rebriev A. V., Tkachuk V. V., Tkachuk L. V., Tkachuk Z. Yu. Mass spectrometry based analisis of syntetic oligonucleotids and oligonucleotids-proteins systems $/ / 3^{\text {rd }}$ Int. Symp. Intracellular Signaling and Bioactive Molecules Design (Lviv, Ukraine, 17-23 September 2012): Abstracts book.-Lviv, 2012.-P. 88

58. Skorobogatov O., Kozlov O. V., Zhukov I. Yu., TkachukZ. Yu. 2'5 -oligoadenilate alters some proteins conformation $/ / 3^{\text {rd }}$ Int. Symp. Intracellular Signaling and Bioactive Molecules Design (Lviv, Ukraine, 17-23 September 2012): Abstracts book.-Lviv, 2012.-P. 94.

59. Pat. US 6, 737, 271. Compound, compozision and method for treatment of inflammatory and inflammatory-related disorders / Z. Tkachuk // Publ. May 18, 2004.-P. 38.

60. Frolov V. M., TkachukZ. Yu., Kruglova O. A. Application of immunomodulator Nucleinat in clinical practice // Infectious Diseases.-2012.-N 4-P. 82-90.

61. Pat. US 8,420,617 B2. Multiantivirus compound, composition and method for treatment of virus disease / Z. Tkachuk // Publ. Apr. 16 2013.-P. 38. 